\title{
Breast Cancer TNM Finding v8
}

National Cancer Institute

\section{Source}

National Cancer Institute. Breast Cancer TNM Finding v8. NCI Thesaurus. Code C139390.

A finding about one or more characteristics of breast cancer, following the rules of the TNM AJCC v8 classification system. This classification system applies to invasive (infiltrating) carcinoma of the breast and ductal carcinoma in situ of the breast. It does not apply to breast sarcoma, phyllodes tumor, and breast lymphoma. (from AJCC 8th Ed.) 